\title{
DIATOM ASSOCIATIONS IN SHELF WATERS OFF PARANÁ STATE, SOUTHERN BRAZIL: ANNUAL VARIATION IN RELATION TO ENVIRONMENTAL FACTORS
}

\author{
Luciano Felicio Fernandes $^{1}$ \& Frederico Pereira Brandini ${ }^{2}$ \\ ${ }^{1}$ Universidade Federal do Paraná, Departamento de Botânica \\ Setor de Ciências Biológicas, Centro Politécnico \\ (Caixa Postal 19031 Jardim das Américas, 81531-970, Curitiba, Paraná, Brasil) \\ E-mail: 1ff@ufpr.br \\ ${ }^{2}$ Centro de Estudos do Mar, Universidade Federal do Paraná \\ (Av. Beira-mar, s.n., 83255-000, Pontal do Paraná, PR, Brasil)
}

\begin{abstract}
A B S T R A C T
The seasonal variation of diatoms in the inshore waters off Paraná State, Southern Brazil was investigated to analyse their temporal dynamics and to detect the main environmental constraints of the planktonic community. Biomass peaks occurred from May to August and from December to March. Among the microplanktonic diatoms, Cerataulina pelagica, Chaetoceros spp., Dactyliosolen fragilissimus, Guinardia striata, Lauderia annulata, Leptocylindrus spp., Pseudo-nitzschia cf. delicatissima, P. australis, Rhizosolenia spp., Skeletonema costatum and Thalassionema nitzschioides were dominant species. Nanoplanktonic diatoms were dominated by Naviculaceae, Nitzschia spp., Thalassiosira spp. and Chaetoceros cf. tenuissimus. Concentrations of most of the species decreased during and just after the blooms of Phaeocystis pouchetii in September and of Coscinodiscus wailesii in April. Based on cluster analysis and interpretations of the environmental parameters monitored, six diatom associations were discerned. Four main environmental factors were attributed as the determinants for the grouping: (a) the stronger influence of the tropical oligotrophic waters of the Brazil Current in spring/summer, (b) the alternation between dry and rainy (nutrient-richer) seasons, (c) the influence of subantarctic waters mixed with coastal ones in fall/winter, bringing cold species and promoting the growth of autochthonous species, and (d) the blooms of nanoplanktonic (Phaeocystis) and microplanktonic (C. wailesii) species.
\end{abstract}

\section{R E S U O}

A variação sazonal das diatomáceas em águas neríticas do estado do Paraná, Sul do Brasil, foi investigada para analisar sua dinâmica temporal e detectar as principais forçantes ambientais da comunidade planctônica. Picos de biomassa ocorreram de Maio a Agosto e de Dezembro a Março. As espécies dominantes foram Cerataulina pelagica, Chaetoceros spp., Dactyliosolen fragilissimus, Guinardia striata, Lauderia annulata, Leptocylindrus spp., Pseudo-nitzschia cf. delicatissima, P. australis, Rhizosolenia spp., Skeletonema costatum e Thalassionema nitzschioides. Representantes de Naviculaceae, Nitzschia spp., Thalassiosira spp. e Chaetoceros cf. tenuissimus dominaram as diatomáceas nanoplanctônicas. As concentrações da maioria das espécies decresceram durante e logo após as florações de Phaeocystis pouchetii em Setembro, e de Coscinodiscus wailesii em Abril. Com base na análise de cluster e interpretações dos parâmetros ambientais monitorados, seis associações de diatomáceas foram discernidas. Quatro fatores ambientais principais foram atribuídos como determinantes para o grupamento: (a) influência mais forte de águas oligotróficas da Corrente do Brasil na Primavera/Verão, (b) alternância entre as estações chuvosa (rica em nutrientes) e seca, (c) influência de águas subantárticas enriquecidas misturadas às costeiras no Outono e Inverno, trazendo espécies de águas frias, além de promover o crescimento de autóctones, e (d) florações de espécies nanoplanctônicas (Phaeocystis) e microplanctônicas (C. wailesii).

Descriptors: Bacillariophyta, Diatoms, Phytoplankton, Southern Brazil, Southwestern Atlantic.

Descritores: Bacillariophyta, Diatomáceas, Fitoplâncton, Taxonomia, Ecologia, Sul do Brasil. 


\section{INTRODUCTION}

Phytoplankton studies of South Brazilian waters have documented its composition, distribution, biomass and primary productivity in relation to hydrographic conditions (see review of Brandini et al., 1997 and references therein; Fernandes \& Brandini, 1999). As for other investigations carried out in different marine ecosystems around the world, these works have found that diatoms (Bacillariophyta) are responsible for high cell densities and most of the primary productivity. They dominate the phytoplankton community in midshelf and coastal regions of southeastern Brazil, gradually diminishing oceanwards, where the relative contribution of dinoflagellates and nanoplankton increases (Brandini \& Fernandes, 1996; Brandini et al., 1997). The environmental factors determining the changes in the structure of diatom associations in coastal areas off South Brazil appear to be seasonal fluctuations in the hydrographic regime and land drainage, which affect temperature, salinity and nutrient concentrations (Brandini, 1990). The study region also exhibits a distinctive seasonal oceanographic pattern due to the proximity of the northern limits of the Brazil-Malvinas Confluence Zone, making ecological studies on diatoms more interesting. The Brazil Current transports warm, oligotrophic tropical waters southwards, dominating oceanic and shelf areas. Off Rio Grande State (38$42^{\circ} \mathrm{S}$ ), the tropical waters meet the colder, nutrientrich waters of the Malvinas Current flowing northwards over the shelf and continental slope of Argentina and Uruguay, which are also greatly affected by freshwater discharges from the La Plata river and the Patos Lagoon (Boltovskoy, 1981; Hubold 1980, 1980a). The influence of the Malvinas Current is stronger in the winter, when the penetration of a tongue of subantarctic waters is regularly detected along the south Brazilian continental shelf (Campos et al., 1996).

The papers on plankton ecology in Brazilian waters describe annual variations in several dominant diatom taxa at the generic level (e. g. Chaetoceros spp., Nitzschia spp., Thalassiosira spp.), or they are referred to as "centric" and "pennate" diatoms. Few works follow the annual variation of dominant diatoms and discuss the environmental conditions influencing their specific composition (e.g. Valentin et al., 1986). As a result, the published textbooks on phytoplankton (e. g. Harris, 1986; Smayda, 1980; Werner, 1977) provide limited information on the ecology and biogeography of diatoms over the extensive Brazilian continental shelf.
Many floristic and taxonomic works have been published on the coastal waters off Paraná State, but again not including enough ecological information (see Moreira Filho et al., 1990 for review and list of species). Brandini (1985, 1985a, 1990) described the spatio-temporal dynamics of phytoplankton groups, chlorophyll-a and primary production in oceanic and shelf waters, discussing their association with hydrographic and climatologic regimes.

The present work describes the annual variation of diatom associations at a coastal station off Paraná State, South Brazil, searching for a better understanding of their peak occurrence in relation to the environmental conditions throughout the year.

\section{Material And Methods}

The sampling station was located at $48^{\circ} 15^{\prime} 30^{\prime \prime} \mathrm{W}$ and $25^{\circ} 37^{\prime} 30^{\prime \prime} \mathrm{S}, 5.4$ nautical miles off the entrance of the Bay of Paranaguá, Paraná State, Southern Brazil (Fig. 1). Local depths ranged from 16 to 18 meters, depending on the tidal variation. Water samples were collected every 7-15 days for one year from May 1990 to April 1991, at 0, 2.5, 5, 10 and 15 meters depth, using a 3.5 liters Van Dorn bottle.

Water samples $(100 \mathrm{ml})$ were preserved with buffered formaldehyde solution $(0,4 \%)$ for diatoms and thecate dinoflagellates; and with Lugol's acetic solution for athecate dinoflagellates and nanoflagellates (Throndsen, 1978). Cell counts were made by allowing $25 \mathrm{ml}$ of subsample to settle over $24 \mathrm{hs}$ in Utermöhl chambers for inverted microscope analysis (Hasle, 1978). At least 500 individuals of all dominant diatoms were counted, reducing the counting error to $10 \%$ (Venrick, 1978). Microplankton and nanoplankton cells were observed at magnifications of $160 x$ and $400 x$, respectively. Results show average density values of the five depths sampled, except when absolute values for each depth were required. Spectrophotometric measurements of chlorophyll-a were estimated by means of extractions with $90 \%$ acetone according to Strickland \& Parsons (1972).

A quantitative cluster analysis of diatom taxa (and interpretations from the field data) was performed to detect groups and their environmental constraints, according to Krebs (1989). Selection of species for analysis was based on abundance $(>4000$ cells. $1^{-1}$ ), frequency of species (at least $10 \%$ ) in the samples, or ecologically relevant characteristics such as biovolume, thermal preferences, etc. The Pearson correlation coefficient complement was used as a measure of distance for the delimitation of diatom groups, and the Euclidean distances of cell densities 
for the sampling dates (Digby \& Kempton, 1987; Krebs, 1989).

Samples for taxonomic analysis of diatoms were obtained by vertical net towing $(20 \mu \mathrm{m}$ mesh) from bottom to surface. Permanent slides were prepared according to Hasle \& Fryxell (1970) for species identification with optical (Olympus BX40) and scanning electron (Phillips LX30) microscopes.

Water temperature and salinity, as well as major inorganic nutrients, were measured according to Strickland \& Parsons (1972). Water transparency was measured with Secchi disc, and the equation of Holmes (1970) was used to calculate the extension of the euphotic zone. Rainfall and wind data were provided by the meteorological station of the National Institute of Meteorology, Paranaguá City, located about $10 \mathrm{~km}$ from our sampling station.

\section{RESUlts}

\section{Environmental Conditions}

The seasonal pattern of precipitation (Fig. 2) was similar to previous years, with rainy periods from January to March, decreasing over the rest of the year, especially in winter, although July also had high values. Win $\mathrm{d}$ regime was frequently dominated by moderate (2.1-4.0 m.s $\mathrm{s}^{-1}$ ) northeast winds, and by moderate to strong $\left(4.0-8.3 \mathrm{~m} . \mathrm{s}^{-1}\right)$ southeast and east winds. The latter are the main determinants of the sea and weather conditions over the region. During the period, frequent intrusions of polar air masses invaded the region, sometimes accompanied by strong winds $\left(4.5-7.3 \mathrm{~m} \cdot \mathrm{s}^{-1}\right)$. North and west winds were rarely dominant $(<10 \%)$ over the study period, at low intensity (less than $2.1 \mathrm{~m} \cdot \mathrm{s}^{-1}$ ).

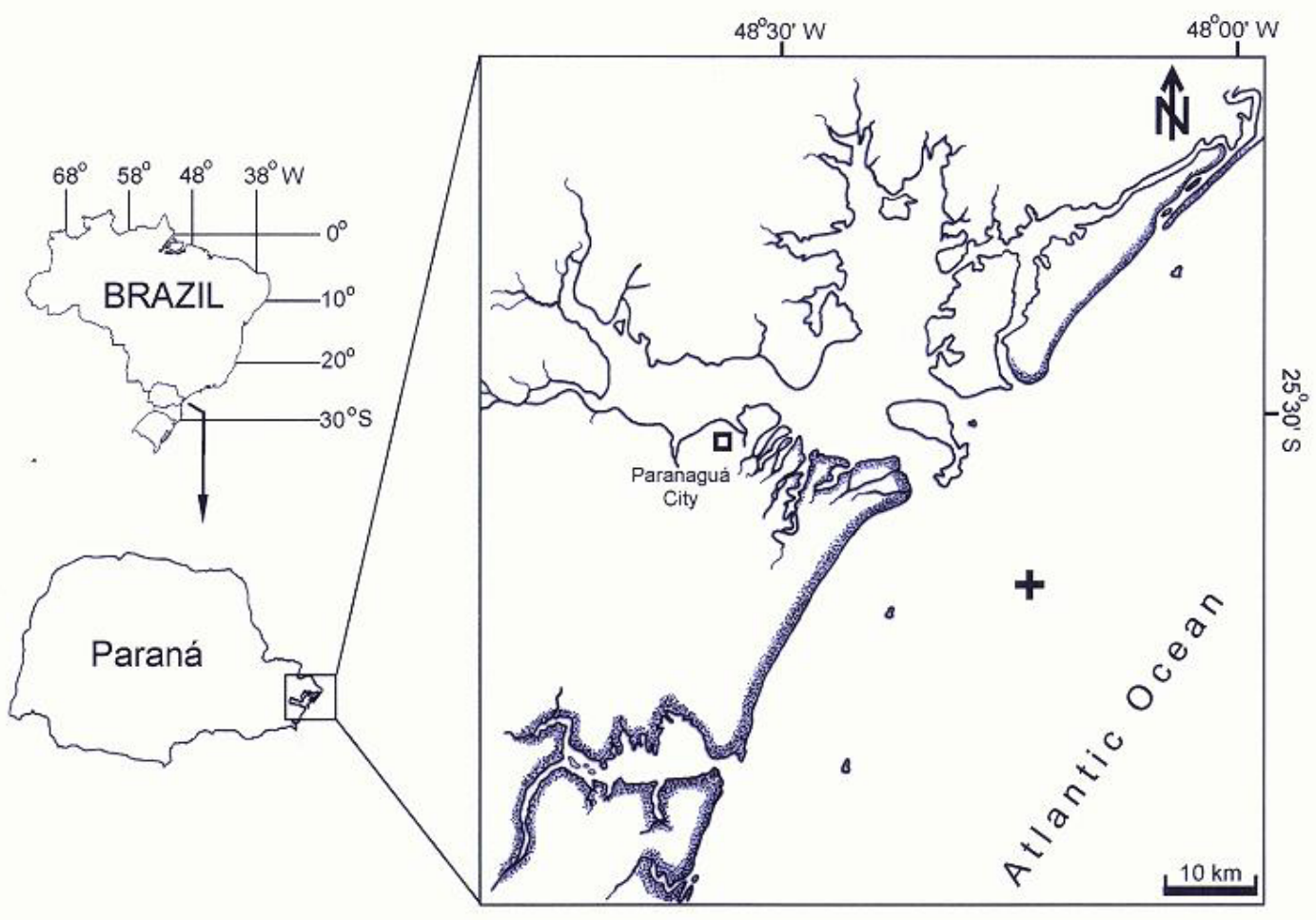

Fig. 1. Map of the study area, showing the sampling station (+). 


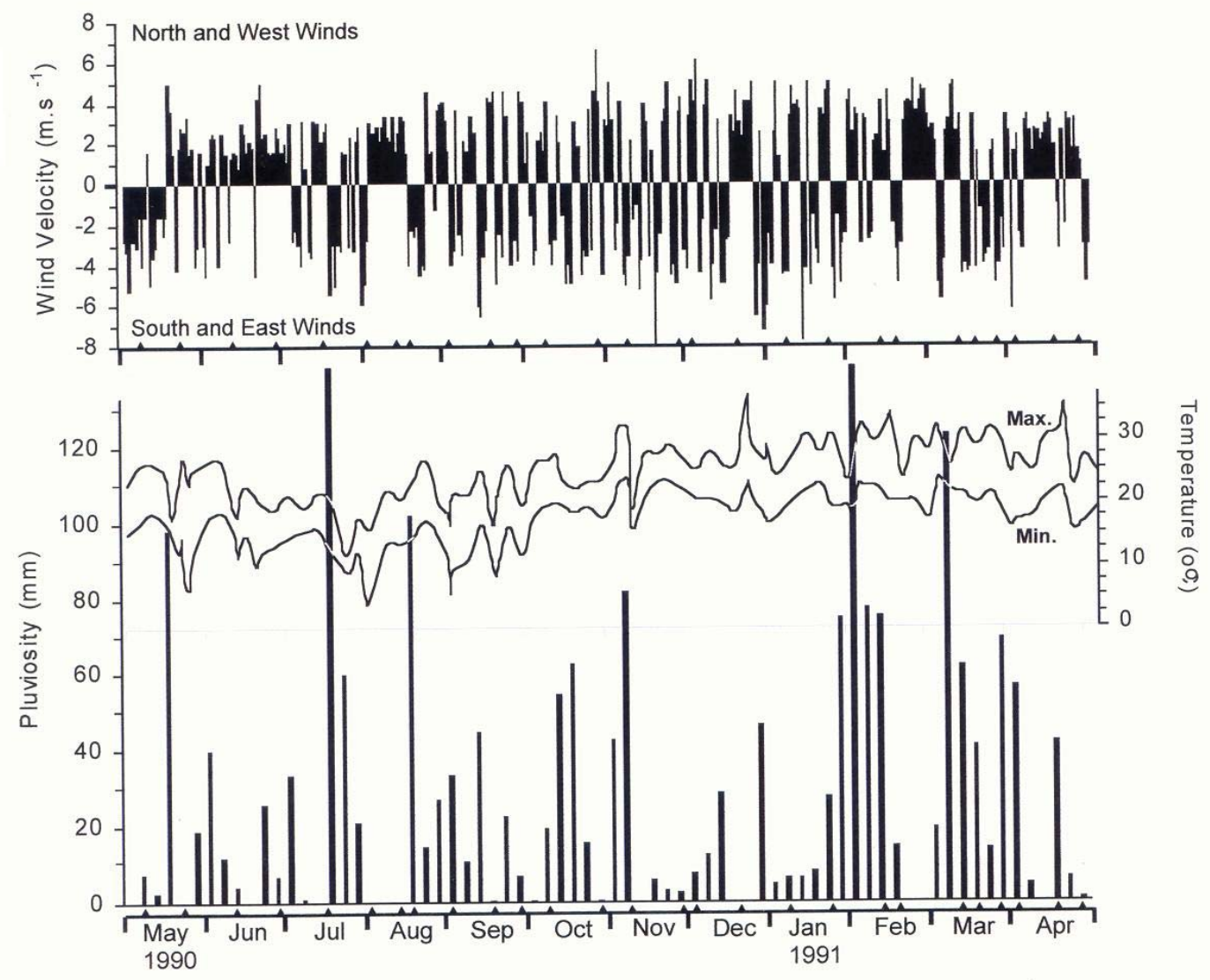

Fig. 2. Climatological parameters recorded from May/1990 to April/1991 in the study region. Wind velocity (upper panel) is expressed as daily values. North and west wind components were plotted on the positive axis, south and east components on the negative axis. In the graph for rainfall, values represent the sum of five days.

Water temperature (Fig. 3) was usually homogeneous throughout the water column, except from January to March, when thermal stratification occurred near the surface. During winter, temperature varied from less than $17^{\circ} \mathrm{C}$ to $20^{\circ} \mathrm{C}$, gradually increasing to $27^{\circ} \mathrm{C}$ in summer.

The lowest salinities (Fig. 3) were always recorded at the surface, ranging from 29.5 to 33.5 , and increasing to 36.5 near the bottom. From August to December and February to April, salinity stratification was observed in the water column, oscillating between 33.0 and 36.5. In other months, the water column maintained homogeneous, with lower values near the surface.

Nitrate concentrations (Fig. 3) varied from less than 0.20 to $1.02 \mu \mathrm{M}$, with higher surface values $(>0.50 \mu \mathrm{M})$ from May to June, and in the whole water column in January. Nitrite concentrations were very low, usually below $0.10 \mu \mathrm{M}$. Phosphate varied from 0.23 to $1.18 \mu \mathrm{M}$, with highest values from May to July $(0.39-1.18 \mu \mathrm{M})$, in January $(0.48-0.81 \mu \mathrm{M})$ and in April $(0.48-0.68 \mu \mathrm{M})$, usually near the bottom. Values were below $0.40 \mu \mathrm{M}$ from August to early November. Concentrations of silicate varied from 5.5 to $51.9 \mu \mathrm{M}$, with highest values occurring from August to early October $(20.1-47.3 \mu \mathrm{M})$ at the surface, and November to January (23.04-51.9 $\mu \mathrm{M})$ near the bottom. The lowest values were detected from May to July in the upper 10 meters (5.4-24.2 $\mu \mathrm{M})$, and in April (12.5-29.2 $\mu \mathrm{M})$.

Light extinction coefficient (k) varied between 0.58 and 0.32 , calculated from Secchi disk readings ranging from 2.5 to 4.5 meters. From these values, the estimated $1 \%$ light penetration varied from 6.5-12.0 meters (Fig. 4), indicating permanently aphotic conditions below 8.0-9.0 meters. 
Temperature $(\mathcal{C})$

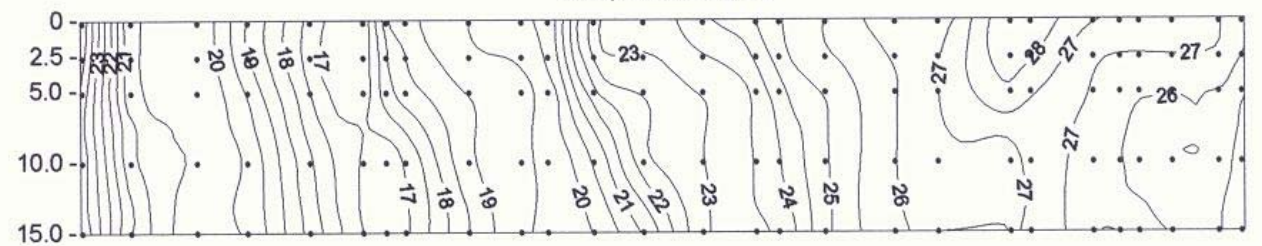

Salinity
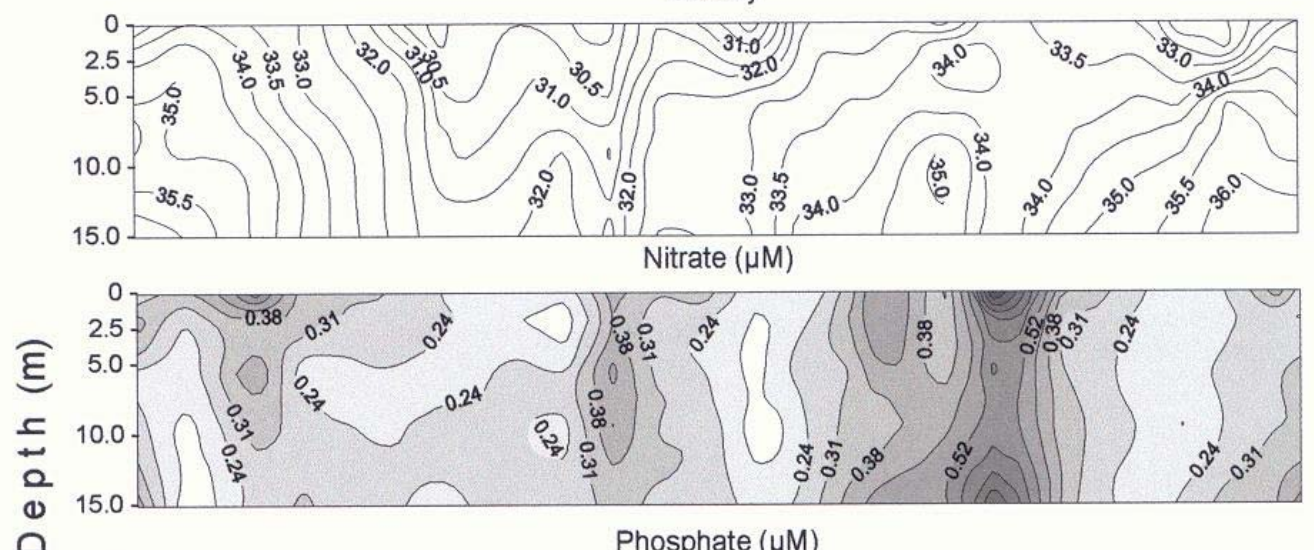

口
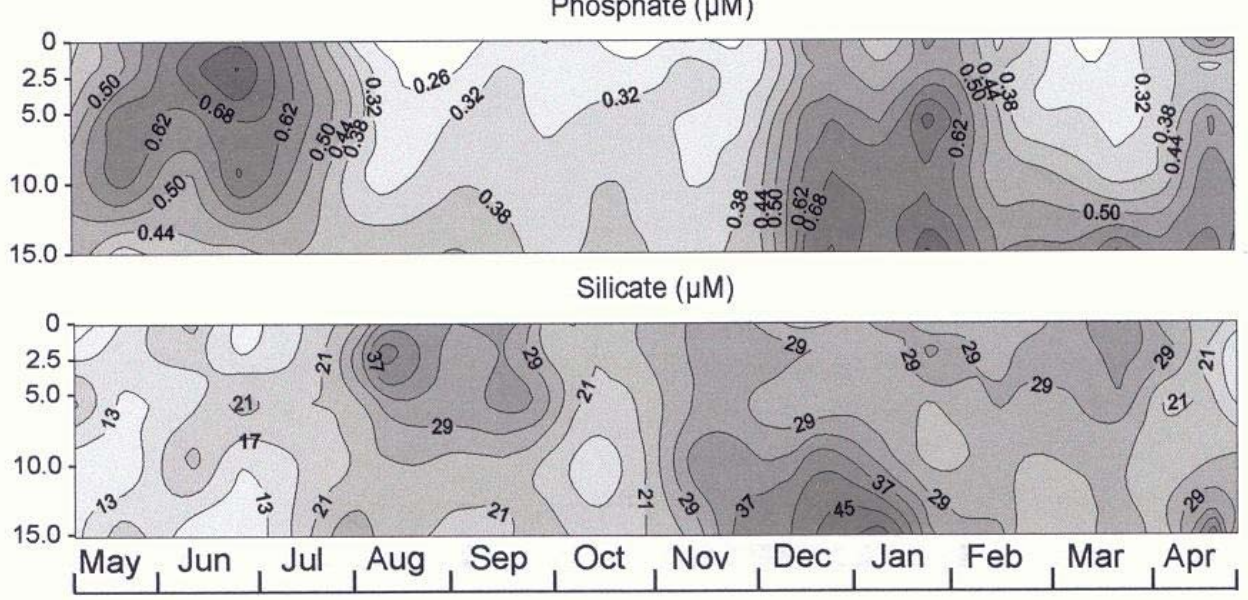

Fig. 3. Vertical distributions of hydrographic parameters from May/1990 to April/1991 at the sampling station off Paranaguá, Paraná, Brazil. Points $(\bullet)$ on graph of water temperature represent the sampling depths.

Vertical distributions of chlorophyll-a and diatom densities in depth and time

Figure 4 shows the vertical distributions of chlorophyll-a and diatom abundances in the $>10 \mu \mathrm{m}$ size fraction. As a general pattern, chlorophyll-a tended to increase from surface to bottom. High values of chlorophyll were observed throughout the water column during the diatom blooms in May and June (up to $1.2 \times 10^{6}$ cells. $1^{-1}$ ). In August, diatoms were abundant near the bottom. In September, both chlorophyll and cell densities decreased, maintaining low densities until early January (except for November). Abundances and chlorophyll-a were high from January to March. In April, when a bloom of $C$. wailesii occurred, cell densities were low but chlorophyll values were high $\left(>3.78-4.72 \mathrm{mg} . \mathrm{m}^{-3}\right.$ at bottom depths), due to the large biovolume and the chlorophyll content of $C$. wailesii. 


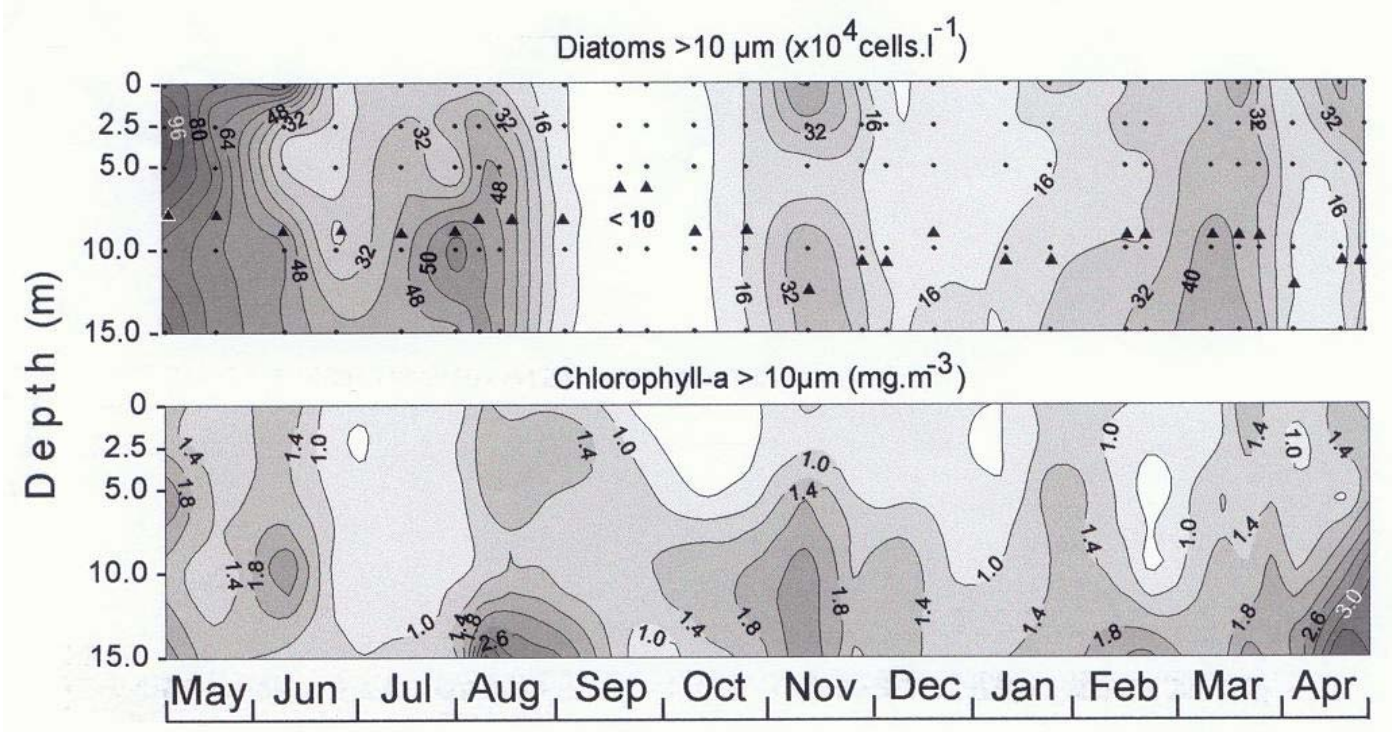

Fig. 4. Vertical distributions of microplanktonic diatoms and chlorophyll-a from May/1990 to April/1991 at the sampling station off Paranaguá, Paraná, Brazil. Depth of euphotic zone (1\%) is indicated by $(\mathbf{\Delta})$.

Annual variation of diatoms and other phytoplankton groups in different size classes

Average densities of microplankton $(>20$ $\mu \mathrm{m})$ cells ranged from $6.0 \times 10^{4}$ to $9.6 \times 10^{5}$ cells. ${ }^{-1}$ (Figs 5 and 6) with diatoms as the dominant group $\left(5.4 \times 10^{4}-9.6 \times 10^{5}\right.$ cells. $\left.^{-1}\right)$. They accounted for most of the phytoplankton cells, and should be responsible for the bulk of chlorophyll-a ( $>$ $10 \mu \mathrm{m})$ concentrations. Diatoms were very abundant from May to August $\left(2.6 \times 10^{5}-9.6 \times 10^{5}\right.$ cells. $\left.^{-1}\right)$, decreasing from September to January $10\left(5.5 \times 10^{4}\right.$ -

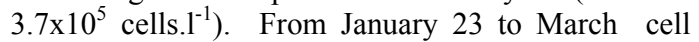

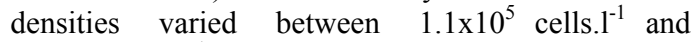
$4.1 \times 10^{5}$ cells. $1^{-1}$. Abundances were low again in April $\left(1.1 \times 10^{5}-2.9 \times 10^{5}\right.$ cells..$\left.^{-1}\right)$. In this month, a bloom of Coscinodiscus wailesii (with $290 \mu \mathrm{m}-410 \mu \mathrm{m}$ valvar diameter and $180 \mu \mathrm{m}-240 \mu \mathrm{m}$ pervalvar axis) occurred, reaching densities up to $5.6 \times 10^{3}$ cells. $1^{-1}$.

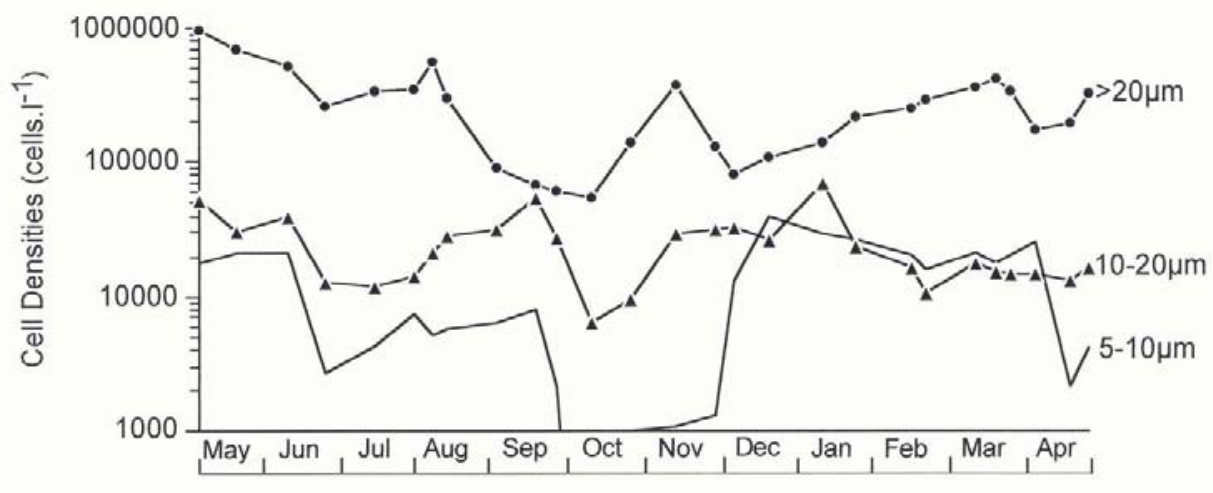

Fig. 5. Annual variation of diatoms in different size classes at the sampling station, expressed as cell densities. Note logarithmic scale on the axis for cell densities. Values are averages from the five depths sampled. 

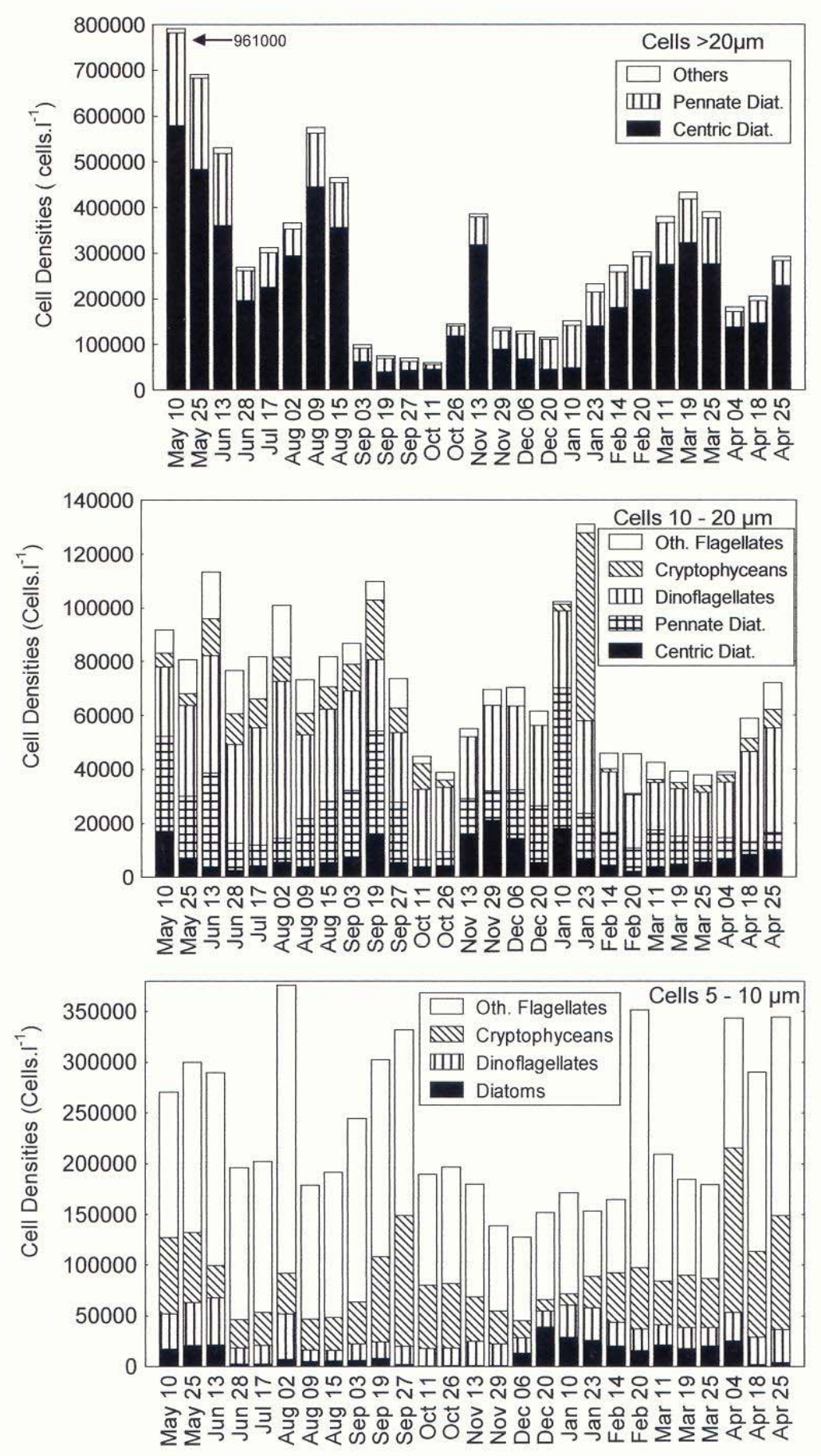

Fig. 6. Annual variation of diatoms and other groups of the phytoplankton in different size classes, expressed as cell densities. Values are averages from the five depths sampled. 
The nanoplankton $(2-20 \mu \mathrm{m})$ was studied in three size classes. In the $10-20 \mu \mathrm{m}$ size class (Figs 5 and 6) diatoms were also important $\left(9.4 \times 10^{3}-7.4 \times 10^{4}\right.$ cells. $\left.1^{-1}\right)$, the highest values being detected on May 10, September 19, and January 10. Centric diatoms varied from $2.1 \times 10^{3}$ to $3.8 \times 10^{4}$ cells. $1^{-1}$, and pennate diatoms from $5.2 \times 10^{3}$ to $5.2 \times 10^{4}$ cells. $1^{-1}$, mainly epiphytic on chain-forming species of Bacteriastrum spp. and Chaetoceros spp.. Thalassiosira spp. (4 species), Nitzschia spp. (3 species) and two non-identified species of Naviculaceae were often present. In the 5-10 $\mu \mathrm{m}$ size class (Figs 5 and 6), diatoms were poorly represented ranging from less than $1.0 \times 10^{3}$ to $3.9 \times 10^{4}$ cells. $1^{-1}$, with peaks in May, June, December and January. Identification of species with light microscopy was difficult, but pennate diatoms resembling Nitzschia and Fragilaria, and the small species Chaetoceros cf. tenuissimus $(4-6 \mu \mathrm{m})$ were frequently observed. Phytoflagellates and gymnodiniaceans were dominant, occurring at densities between $1.4 \times 10^{5}$ and $3.7 \times 10^{5}$ cells. $1^{-1}$. In the 2-5 $\mu \mathrm{m}$ size class (Fig. 5), the contribution of diatoms was low (less than $4.0 \times 10^{4}$ cells. $^{-1}$ ). Phytoflagellates dominated, with $8.7 \times 10^{4}$ to $8.6 \times 10^{5}$ cells. $1^{-1}$. From August to September, a bloom of Phaeocystis pouchetii in gelatinous colonies (up to

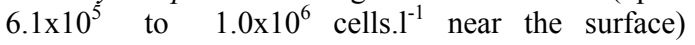
occurred. From October to April, flagellate densities tended to diminish, varying between $8.7 \mathrm{x}$ $10^{4}$ cells. $^{-1}$ and $3.1 \times 10^{5}$ cells. $1^{-1}$, and the lowest values were detected in April, during the bloom of $C$. wailesi.

Annual variation of abundant species and groups of diatoms

The bulk of the diatom biomass was made up of chain-forming species. Figure 7 shows the annual variation of cell densities (averaged from the five depths sampled) of 27 abundant species or higher taxonomic groups. Two prominent growth episodes (May-August and January-March) were detected (confirmed by Cluster analysis), when Cerataulina pelagica, Chaetoceros spp., Dactilyosolen fragilissimus, G. striata, Lauderia annulata, Leptocylindrus spp., Pseudo-nitzschia spp. and Rhizosolenia spp. (mainly $R$. hebetata followed by $R$. calcaravis, $R$. setigera and $R$. styliformis) dominated. Between these periods, total cell densities tended to decrease, mainly in September, October, January and April. Skeletonema costatum and Thalassionema nitzschioides showed irregular peaks along the study period. In some months, Thalassiosira spp. (May to
August), Hemiaulus spp. (June to August and October to November), Eucampia spp. (November and December) and Coscinodiscus spp. (May, August and October) were important. Large species of Coscinodiscus were abundant in October and November (C. oculus-iridis and C. centralis) and in April (C. wailesii).

Some additional comments about the dominant species within the taxonomic categories represented in the Figure 7 are given. Within Chaetoceros, the most abundant species were $C$. affinis, C. compressus, C. curvisetus, C. debilis and $C$. didymus. The genus Guinardia was composed of $G$. delicatissima and G. striata. B. delicatulum and B. hyalinum composed the genus Bacteriastrum. In "Naviculaceae", a broader taxon composed of many species; Navicula spp. and Mastogloia spp. were abundant, as planktonic and benthic forms.

\section{Cluster Analysis}

The dendrogram produced for temporal patterns of diatoms (Fig. 8a) generated six groups (A - F). The warm species Hemiaulus hauckii and $H$. sinensis and Coscinodiscus spp. comprised Group A. Their maximal abundances occurred not only in October and November, but also in June and July, when water temperatures recorded were the lowest. In Group B, Detonula pumila and $T$. mediterranea were usually scarce, but with sharp peaks in July and August. The position of $S$. costatum in this group could not be explained, since its occurrence pattern was distinct, being abundant throughout the year, and with peaks in July, August and November. Group C contained two subtropical species (E. cornuta and $E$. zoodiacus) but with density peaks from October to November, but at low concentrations for most of the year. The first three groups are related to the influence of warm waters, carrying species to coastal waters, after the late fall/winter diatom bloom. Groups D, E, and F were formed by abundant neritic species from May to July and February to March. They were associated with periods of nutrient enrichment in the water column due to the higher rainfall, and the influence of coastal subantarctic waters. Group D was composed of Bacteriastrum spp. and L. annulata, and their clustering was based on evident peaks in May, June and April. Diatoms in Group E showed peaks in February and March. Group F was influenced by the higher abundances recorded from May to July and from February to March. 

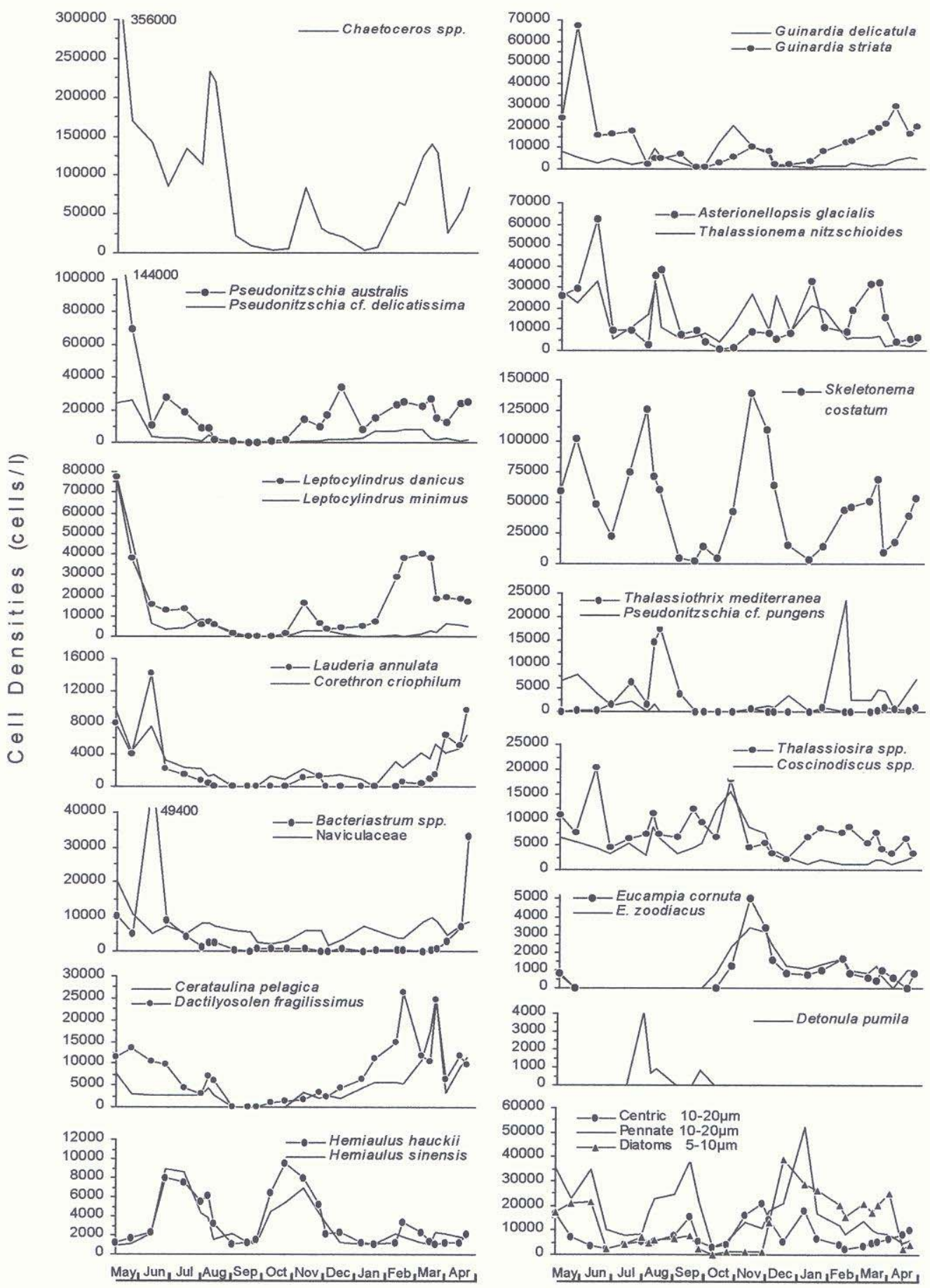

Fig. 7. Annual variation of most important diatom taxa from May/1990 to April/1991 in the sampling station. Note different scales of cell densities in the graphs. Values are averages from the five depths sampled. 
The cluster analysis of sampling dates/cell densities (Fig. 8b) indicated the main environmental factors acting over the region. Group I represented periods of low diatom densities under low nutrient levels due to the stronger influence of oligotrophic waters of the Brazil Current, and when the blooms of Phaeocystis and C. wailesii occurred. Group II probably represents periods of intermediate or diverse environmental conditions, when different stages of diatom growth took place. Groups III and IV were influenced by the higher abundance of dominant species, resulting from the presence of enriched subantarctic waters from May to early August, and the more intense land drainage in March.
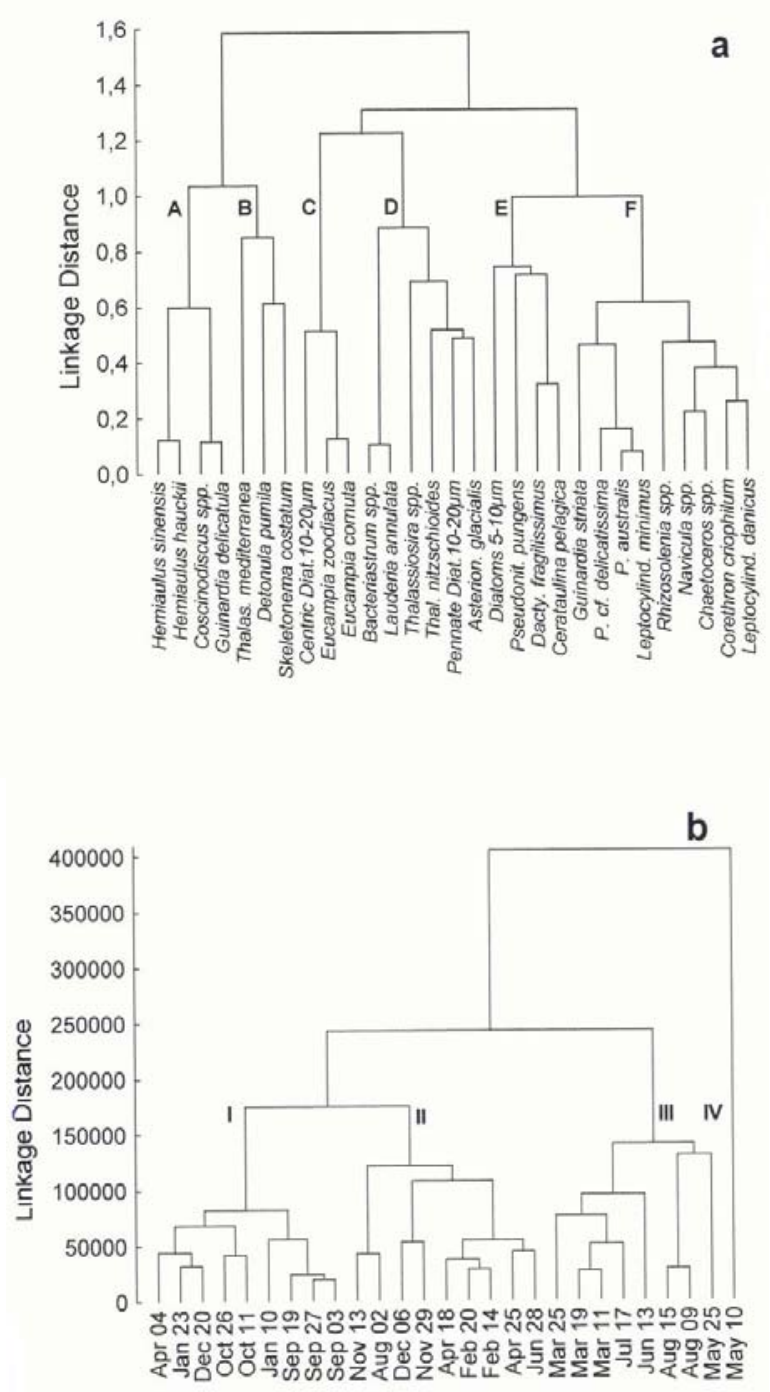

Fig. 8. Quantitative dendrograms for classification of diatom taxa (a) and of sampling dates (b) in the sampling station. Six diatom groups (A-F) were considered as true biological associations. For details, see the text. 


\section{Net Plankton}

Some observations were made on the composition of net plankton diatoms, and Appendix I shows the species found in the present study. A mixed flora of warm and temperate planktonic neritic species formed the majority of the community, and their abundance varied depending upon water mass. During spring and summer, species typical of warm waters appeared frequently, e. g. Climacodium frauenfeldianum, Coscinodiscus centralis, C. gigas, Eucampia spp., Hemiaulus membranaceus, Stephanopyxis turris and, rarely, Gossleriella tropica and Planktoniella sol. In addition, the coccolithophorid Umbilicosphaera sibogae and other tropical/subtropical species of dinoflagellates such as Ceratium azoricum, C. vultur, Corithodinium tesselatum, Podolampas bipes, P. elegans, and Schuttiella mitra were recorded. In winter, cold water species such as Asteromphalus hookerii, Lauderia annulata, Rhisozolenia setigera, Detonula pumila, Thalassiothrix frauenfeldii, Thalassiosira nodulolineata, $T$. poroseriata and $T$. tumida were frequent. Uncommon diatoms in Brazilian waters were Anorthoneis eurystoma, Asteromphalus arachnae, Asteromphalus sarcophagus, Bacteriastrum comosum, Minidiscus chilensis and Porosira pentaportula.

Besides planktonic species, many benthic diatoms were identified in the water column, and were even abundant occasionally. These included Achnanthes sp., Anorthoneis eurystoma, Cyclotella stylorum, Delphineis surirella, Mastogloia spp., Paralia sulcata, Rhaphoneis amphiceros and Thalassiosira spp. (valvar diameters ranging from 10 to $20 \mu \mathrm{m}$ ). The latter are quite similar to those found in groups of three to eight cells aggregating small sand grains (Ernissee \& Abbott, 1975). These benthic species and other dominant tychoplanktonic species as Chaetoceros spp. and $T$. nitzschioides clearly indicate the bottom influence.

\section{Discussion}

The dominance of diatoms within coastal phytoplankton assemblages reflects the physical instability of shallow coastal environments. Turbulence tends to maintain the vertical homogeneity of physical and chemical parameters, maintaining high nutrient concentrations in the euphotic zone due to the ressuspension of sediments (Smetacek, 1985; 1988). In addition, turbulence tends to retard the sinking of species out of the euphotic zone, while land drainage continuously enriches the neritic region and decreases salinity, favoring diatom growth (Margalef, 1978; Smayda, 1980).

In the present study, microplanktonic diatoms were always the dominant autotrophs, occurring at 410 fold higher densities than other groups during the period, except during the period of low biomass in September and October, when nanoplankton dominated. Diatoms also tended to contribute more with chlorophyll-a biomass than the nanoplankton fraction, except in September and October, when a bloom of Phaeocystis pouchetii dominated the phytoplankton, and under the stronger influence of tropical waters carried in the region by the Brazil Current from November to February. Diatoms were also the main primary producers in adjacent areas near our sampling station (Brandini, 1990; 1990a). Their dominance is also reflected in the higher trophic levels, as they represent the principal diet of the dominant copepods (Acartia lilljeborgii, Corycaeus spp., Oncaea spp., Paracalanus quasimodo, Temora turbinata) in the region, which are large omnivorous or herbivorous grazing on microsize particles (Lopes et al., 1998).

As a general pattern, neritic subtropical diatoms dominated throughout the year, under the influence of the Brazil Current and land drainage. However, colder subantarctic waters and blooms of different algal groups also affected the composition and the overall densities of microphytoplankton. May to August comprised the largest diatom pulses, representing Groups $\mathrm{E}$ and $\mathrm{F}$ from the cluster analysis, dominated by Asterionellopsis glacialis, Chaetoceros spp., Guinardia striata, Leptocylindrus spp. and Pseudo-nitzschia spp. Such blooms might be caused by traces of nutrient-rich subantarctic waters mixed with coastal waters, as indicated by the elevated nitrate and phosphate concentrations and the presence of cold-water diatom species. The influence of the freshwater discharges of the La Plata River, as pointed out by Boltovskoy (1981) and Ciotti et al. (1995), must also be taken into account as important factors enriching the Paraná coast during autumn and winter. Coastward intrusion of subantarctic waters over the Brazilian shelf is a common feature of the local hydrographic regime during winter (Boltovskoy, 1981; Brandini, 1990; Campos et al., 1996). Brandini (op. cit.) also observed higher phytoplankton biomass during the winter, associated with the presence of subantarctic waters. Lange (1985) noted a greater influence of the subantarctic flora over the Argentinian shelf in winter. The typical warm species Hemiaulus hauckii and $H$. sinensis also responded to the nutrient enrichment, increasing in abundance in late fall. 
The decrease in diatoms between September and early January (except for the isolated peak in November 13) could be associated with the lower availability of silicate due to uptake during fall/winter blooms. Moreover, precipitation was low compared to other months, diminishing the input of nutrients via land runoff. Cell densities decreased and only Guinardia delicatula, Detonula pumila, Thalassionema nitzschioides and some Naviculaceae were abundant. In contrast, a bloom of Phaeocystis pouchetii took place in September, just after the diatom bloom. As for the seasonal phytoplankton succession observed in the North Sea over the last decades, Phaeocystis becomes dominant after silica depletion and aging of the diatom blooms (Lancelot et al., 1991). In the North Sea such community replacement has been associated with increasing organic pollution, resulting in changes of nutrients and N/P ratios (Riegmann et al., 1992). However, this is not the case on the Paraná coast, where pollution is of minor importance as a factor regulating phytoplankton succession.

Diatom abundance again increased from January 23 to March, when nutrient concentrations near the surface were elevated, due to higher precipitation and concomitant land drainage. In this period, Asterionellopsis glacialis, Cerataulina pelagica, Chaetoceros spp., Dactilyosolen fragilissimus, Guinardia striata, Leptocylindrus danicus, Pseudo-nitzschia spp. and Skeletonema costatum dominated the diatom community. The less pronounced development of diatoms in summer/early fall compared to late fall/winter could be due to the stronger coastward displacement of the oligotrophic Brazil Current waters, mixing with shelf waters (Emílsson, 1960; Brandini, 1990) and diluting nutrients to some extent. The presence of warmspecies and higher salinities (up to 35.0) compared to other periods, confirm the influence of tropical waters in the study area. For comparison, near our sampling station in the mesohaline estuarine waters of Paranaguá Bay, the highest phytoplankton biomass occurred during the rainy period from January to March, when nutrient input via land runoff increased. In contrast to our findings, Skeletonema costatum dominated the community (up to $4.7 \times 10^{6}$ cells..$^{-1}$ ) in the Bay, accounting for more than $90 \%$ of total densities (Brandini, 1985; 1985a).

The bloom of Coscinodiscus wailesii was another important event affecting phytoplankton community structure during April 1991, when densities of diatoms and other phytoplankton groups had fallen, and even zooplankton was almost absent (L. F. Fernandes and R. M. Lopes, unpublished data). Chlorophyll-a concentration was high, due to the large volume of $C$. wailesii cell, associated to its chlorophyll-a content. This bloom persisted until November 1991, and the species became common at Paranaguá Bay in the following years (Fernandes et al., 2001). Despite its large size, this species is fast growing, highly competitive for nutrients, eurioic and inefficiently grazed or even avoided by copepods (Rick \& Dürselen, 1995; Roy et al., 1989). All these factors help to explain why $C$. wailesii has been successful worldwide after invading turbulent coastal waters .

High nutrient concentrations were frequently recorded at 10-15 meters in association with the occurrence of large populations of benthic and tychoplanktonic diatoms. Based on indirect evidence, it seems reasonable that ressuspension of bottom sediments through tidal mixing and wind driven turbulence is responsible for the contribution of benthic diatoms and nutriente regeneration. Studies in coastal areas with similar characteristics have shown that the benthic community is responsible for the regeneration of nutrients to the water column through turbulence (Doering, 1989; Flint \& Kamiakowski, 1983; Zeitschel, 1980). Other positive effects of turbulence on the diatom communities inhabiting the study region are: (i) the maintenance of abundant species in the water column, avoiding their sinking to a permanently aphotic zone; and (ii) the ressuspension of resting cysts and of tychoplanktonic forms such as Chaetoceros (Margalef, 1978; Smetacek, 1985) that are frequently dominant in the study region, allowing completion of their life-cycles.

\section{Acknowledgements}

We thank CNPq (research grant to L.F.F.) and Centro de Estudos do Mar/UFPR for providing financial support and laboratory facilities. Jaqueline Rebello analyzed most of nutrient samples. We are indebted to Dr. Daura R. Stofella (Centro de Microscopia Eletrônica/UFPR) and Paulo Brixel (LACTEC/Paraná) for the assistance with the scanning electron microscope. This work is part of a MSc. Thesis in Botany, UFPR.

\section{REFERENCES}

Boltovskoy, E. 1981. Masas de água en el Atlantico Sudoccidental. In: Boltovskoy, D. ed. Atlas del Zooplancton del Atlântico Sudoccidental y metodos de trabajo con el zooplancton marino. Mar del Plata, Publ esp INIDEP. p. 227-238.

Brandini, F. P. 1985. Seasonal succession of the phytoplankton in the bay of Paranaguá (Paraná state Brazil). Rev. brasil. Biol., 45(4):687-694.

Brandini, F. P. 1985a. Ecological studies in the bay of Paranaguá. I. Horizontal distribution and seasonal dynamics of the phytoplankton. Bolm. Inst. oceanogr. São Paulo, 33(2):139-147. 
Brandini, F. P. 1990. Hydrography and characteristics of the phytoplankton in shelf and oceanic waters off southeastern Brazil during winter (july/august-1982) and summer (February/March-1984). Hydrobiol., 196(2):111-148

Brandini, F. P. 1990a. Produção primária e características fotossintéticas do fitoplâncton na região Sueste do Brasil. Bolm. Inst. oceanogr., S Paulo, 38(2):147159.

Brandini, F. P. \& Fernandes, L. F. 1996. Microalgae of the continental shelf of Paraná State, southern Brazil: review of studies. Bolm. Inst. oceanogr., S. Paulo, 44(1):69-80.

Brandini, F. P.; Lopes, R. M.; Gutseit, K. S.; Spach, H. L. \& Sassi, R. 1997. Planctonologia na plataforma continental do Brasil. Diagnose e revisão bibliográfica. Brasília, Ministério do Meio Ambiente/CIRM/FEMAR. 196p.

Campos, E. J. D.; Lorenzzetti, J. A.; Stevenson, M. R.; Stech, J. L. \& Souza, R. B. 1996. Penetration of waters from the Brazil-Malvinas Confluence region along the South American continental shelf up to $23^{\circ} \mathrm{S}$. An. Acad. Bras. Ci., 68 (Suppl. 1):49-58.

Ciotti, A. M.; Odebrecht, C.; Fillmann, G. \& Möller Jr, O. 1995. Freshwater outflow and Subtropical Convergence influence on phytoplankton biomass on the southern Brazilian continental shelf. Continent. Shelf Res., 15(14): 1737-1756

Digby, P. G. N. \& Kempton, R. A. 1987. Multivariate analysis of ecological communities. London, Chapman and Hall. 450p.

Doering, E. G. 1989. On the contribution of the benthos to pelagic production. J. Mar. Res., 47(2):371-383.

Emílsson, I. 1960. The shelf and coastal waters off the Southern Brazil. Bolm. Inst. oceanogr., S Paulo, 11(único):101-112.

Ernissee, J. J. \& Abbott, W. H. 1975. Binding of mineral grains by a species of Thalassiosira. Nova Hedwigia, Beih., 53:241-252.

Fernandes, L.F. \& Brandini, F.P. 1999. Microplankton communities in Southwestern Atlantic Ocean: biomass and distribution in November 1992. Rev. bras. oceanogr., 47(2):189-205

Fernandes, L. F.; Zehnder-Alves, L. \& Bassfeld, J. C. 2001. The recently established diatom Coscinodiscus wailesii (Coscinodiscales, Bacillariophyta) in Brazilian waters. I. Remarks on morphology and distribution. Phycological Res., 49:89-96.

Flint, R. W. \& Kamiakowski, D. 1984. Benthic nutrient regeneration in South Texas coastal waters. Estuar. Coast. Shelf Sci., 18(2):221-230.

Harris, G. P. 1986. Phytoplankton ecology: structure, function and fluctuation. New York, Chapman and Hall. $384 p$.

Hasle, G. R. 1978. Using the inverted microscopy. In: Sournia, A., ed. Phytoplankton manual. Monogr. Oceanogr. Methodol, U.N. 6:191-196.

Hasle, G. R. \& Fryxell, G. A. 1970. Diatoms: cleaning and mounting for light and electron microscopy. Trans. Am. Microsc. Soc., 89:469-474.

Holmes, R. W. 1970. The Secchi disk in turbid coastal waters. Limnol. Oceanogr., 15:688-694.
Hubold, G. 1980. Hydrography and plankton off Southern Brazil and Rio de la Plata: augustnovember 1977. Atlantica, 4:1-21.

Hubold, G. 1980a. Second report on Hydrography and plankton off Southern Brazil and Rio de la Plata: autumn cruise: april-june 1978. Atlantica, 4:23-42.

Krebs, C. J. 1989. Ecological methodology. New York, Harper Collins Publ. 850p.

Lancelot, C.; Billen, G. \& Barth, H. 1991. The dynamics of Phaeocystis blooms in nutrient enriched coastal zones. Water Pollut., Res. Rep., 23:1-116.

Lange, C.B. 1985. Spatial and seasonal variations of diatom assemblages off the argentinan coast (South Western Atlantic). Oceanol. Acta, 8:361-369.

Lopes, R. M.; Vale, R. \& Brandini, F. P. 1998. Composição, abundância e distribuição espacial do zooplâncton no complexo estuarino de Paranaguá durante o inverno de 1993 e o verão de 1994. Rev. bras. oceanogr. 46(2):195-211.

Margalef, R. 1978. Life-forms of phytoplankton as survival alternatives in unstable environments. Oceanol. Acta, 1:493-509.

Moreira-Filho, H.; Valente-Moreira, I. M.; SouzaMosimann, R. M. \& Cunha, J.A. 1990. Avaliação florística e ecológica das diatomáceas (ChrysophytaBacillariophyceae) marinhas e estuarinas nos estados do Paraná, Santa Catarina e Rio Grande do Sul. Est. Biologia (PUC), 25:5-48.

Rick, H. J. \& Dürselen, C. D. 1995. Importance and abundance of the recently established species Coscinodiscus wailesii Gran et Angst in the German Bight. Helgolander Meeresunters., 49: 355-74.

Riegmann, R.; Noordeloos, A. A. M. \& Cadée, G. C. 1992. Phaeocystis blooms and eutrophication of the coastal zones of the North Sea. Mar. Biol., 112(3):479-484.

Roy, S.; Harris, R. P. \& Pulet, S. A. 1989. Inneficient feeding by Calanus helgolandicus and Temora longicornis on Coscinodiscus wailesii: quantitative estimation using chlorophyll-type pigment and effects on dissolved free amino acids. Mar. Ecol. Prog. Ser., 52:145-53.

Smayda, T. 1980. Phytoplankton species succession. In: Morris, I. ed. The physiological ecology of phytoplankton. Studies in ecology 7. Oxford Blackwell Scient. Publ. p. 493-570.

Smetacek, V. S. 1985. Role of sinking in diatom lifehistory cycles: ecological, evolutionary and geological significance. Mar. Biol., 84:239-251.

Smetacek, V. S. 1988. Plankton characteristics. In: Postma, H. \& Zijlstra, J. J. eds. Ecosystems of the world, Continental shelves, v. 27 Amsterdan, Elsevier. p. 93-130.

Strickland, J. D. H. \& Parsons, T. R. 1972. A pratical handbook of seawater analysis. Bull. Fish. Res. Bd. Can., 122:1-172.

Throndsen, J. 1978. Preservation and storage. In: Sournia, A., ed. Phytoplankton manual. Monogr oceanogr. Methodol., V.N., 6: 69-74. 
Valentin, J. L.; Lins da Silva, N. M.; Monteiro-Ribas, W. M.; Mureb, M. A.; Bastos, C. T. B. T.; Tenembaum, D. R.; André, D. L.; Jacob, S. A. \& Pessotti, E. 1986. Le plancton dans l'upwelling de Cabo Frio (Brésil): microrépartition spatio-temporale à une station fixe. Ann. Inst. océanogr., Paris, Nouv. Serv., 62:117-135.

Venrick, E.L. 1978. How many cells to count? In: Sournia, A. ed. Phytoplankton manual. Monogr. oceanogr. Methodol., V.N., 6:167-180.

Werner, D. ed. 1977. The biology of diatoms. Ecolog. Monogr., 13. Los Angeles, University of California Press. 498p.

Zeitschel, B. 1980. Sediment-water interactions. In: Tenore, K. R. \& Coull, B. C. eds. Marine benthic dynamics. South Carolina, University of South Carolina Press. p. 195-218.

(Manuscript received 07 May 2003; revised 15 September 2003; accepted 06 October 2003) 
Appendix 1. Diatom taxa recorded during the sampling period in the coastal station off Paranaguá, Paraná, Southern Brazil.

\begin{tabular}{|c|c|}
\hline Achnanthes curvirostrum Brun & Cocconeis scutellum Ehrenberg \\
\hline Achnanthes fimbriata (Grunow) Ross & Corethron criophilum Castracane \\
\hline Achnanthes sp. & Coscinodiscus asteromphalus Ehrenberg \\
\hline Actinocyclus ehrenbergii Ralfs & Coscinodiscus centralis Ehrenberg \\
\hline A. ehrenbergii var. ralfsii (Wm.Smith) Hustedt & Coscinodiscus curvatulus Grunow \\
\hline Actinoptychus campanulifer A. Schmidt & Coscinodiscus gigas Ehrenberg \\
\hline Actinoptychus undulatus (Bailey) Ralfs & Coscinodiscus granii Gough \\
\hline Actinoptychus vulgaris Schumann & Coscinodiscus jonesianus (Greville) Ostenfeld \\
\hline Amphiprora alata (Ehrenberg) Kutzing & Coscinodiscus kutzingii A. Schmidt \\
\hline Amphiprora gigantea Grunow & Coscinodiscus obscurus A. Schmidt \\
\hline Amphiprora sp. & Coscinodiscus oculus-iridis Ehrenberg \\
\hline Amphora arenaria Donkin & Coscinodiscus rothii (Ehrenberg) Grunow \\
\hline Amphora spp. & Coscinodiscus wailesii Gran and Angst \\
\hline Anorthoneis eurystoma Cleve & Coscinodiscus spp. \\
\hline Asterionellopsis glacialis (Castracane) F.E. Round & Cyclotella litorallis Lange \& Syvertsen \\
\hline Asteromphalus arachne (Brébisson) Ralfs & Cyclotella stylorum Brightwell \\
\hline Asteromphalus heptactis (Brebisson) Ralfs & Cylindrotheca closterium (Ehrenberg) Reimer \\
\hline Asteromphalus hookerii Ehrenberg & Cymatodiscus planetophorus (Meister) Hendey \\
\hline Asteromphalus sarchofagus Wallich & Cymatonitzschia marina (Lewis) Simonsen \\
\hline Bacillaria paradoxa Gmelin & Cymatotheca weissflogii (Grunow) Hendey \\
\hline Bacteriastrum comosum Pavillard & Dactyliosolen fragilissimus (Bergon) Hasle \\
\hline Bacteriastrum delicatulum Cleve & Dactyliosolen mediterraneus H. Peragallo \\
\hline Bacteriastrum hyalinum Lauder & Delphineis surirella (Grunow) Andrews \\
\hline B. hyalinum var. princeps (Castracane) Ikari & D. surirella var. australis (Grunow) Andrews \\
\hline Bacteriastrum varians Lauder & Dimerogramma marinum (Gregory) Ralfs \\
\hline Biddulphia longicruris Greville & Dimerogramma minor (Gregory) Ralfs \\
\hline Biddulphia rhombus (Ehrenberg) W. Smith & Diploneis bombus Ehrenberg \\
\hline Biddulphia tridens (Ehrenberg) Ehrenberg & Diploneis crabro (Ehrenberg) Ehrenberg \\
\hline Campylodiscus ecclesianus Greville & Diploneis smithii (Brebisson) Cleve \\
\hline Campylosira cymbeliformis (A. Schmidt) Grunow & Diploneis weissflogii (A. Schmidt) Cleve \\
\hline Cerataulina pelagica $\mathrm{H}$. Peragallo & Diploneis sp. \\
\hline Chaetoceros affinis Lauder & Ditylum brightwellii (West) Grunow \\
\hline Chaetoceros coarctatus Lauder & Donkinia reta (Cleve) Cox \\
\hline Chaetoceros compressus Lauder & Eucampia cornuta (Cleve) Grunow \\
\hline Chaetoceros costatum Pavillard & Eucampia zoodiacus Ehrenberg \\
\hline Chaetoceros curvisetum Cleve & Fragilariopsis doliolus (Wallich) Medlin and Sims \\
\hline Chaetoceros danicus Cleve & Grammatophora marina (Lyngbie) Kutzing \\
\hline Chaetoceros debilis Cleve & Guinardia delicatula (Cleve) Hasle \\
\hline Chaetoceros decipiens Cleve & Guinardia flaccida (Castracane) Peragallo \\
\hline Chaetoceros didymus Ehrenberg & Guinardia striata (Stolterfoth) Hasle \\
\hline Chaetoceros diversus Cleve & Gyrosigma balticum (Ehrenberg) Rabenhorst \\
\hline Chaetoceros eibenii (Grunow) Meister & Gyrosigma exoticum Cholnoky \\
\hline Chaetoceros laevis Leuduger-Fortmorel & Gyrosigma scalproides (Rabenhorst) Cleve \\
\hline Chaetoceros lauderi Ralfs & Hemiaulus hauckii Grunow \\
\hline Chaetoceros lorenzianus Grunow & Hemiaulus membranaceus Cleve \\
\hline Chaetoceros messanensis Castracane & Hemiaulus sinensis Greville \\
\hline Chaetoceros pendulus Karsten & Hemidiscus cuneiformis Wallich \\
\hline Chaetoceros peruvianus Brightwell & Lauderia annulata Cleve \\
\hline Chaetoceros socialis Lauder & Leptocylindrus danicus Cleve \\
\hline Chaetoceros cf. tenuissimus Meunier & Leptocylindrus minimus Gran \\
\hline
\end{tabular}


Cont. Appendix 1.

Climacodium frauenfeldianum Grunow

Licmophora clevei Hustedt

Lithodesmium undulatum Ehrenberg

Lyrella abruptoides (Hustedt) D.G. Mann

Lyrella barbara (Heiden and Kolbe) D.G. Mann

Lyrella hennedyi (Wm. Smith) Stickle and Mann

Lyrella lyra (Ehrenberg) D.G. Mann

Margaritum terebro (Leuduger F.-Morel) H.

Moreira

Mastogloia acutiuscula Grunow

Mastogloia angulata Lewis

Mastogloia apiculata Wm. Smith

Mastogloia decussata Grunow

Mastogloia exigua Lewis

Mastogloia meisterii Hustedt

Mastogloia pumilla (Grunow) Cleve

Mastogloia spp.

Minidiscus chilensis Rivera and Koch

Navicula crucicula (Wm. Smith) Donkin

Navicula pennata A. Schmidt

Navicula yarrensis Grunow

Navicula spp. (4 species)

Nitzschia longissima (Brebisson) Ralfs

Nitzschia ventricosa Kitton

Nitzschia spp.

Odontella aurita (Lyngbie) Simonsen

Odontella mobiliensis (Bailey) Simonsen

Odontella sinensis (Greville) Simonsen

Odontella sp.

Palmeria hardmaniana Greville

Paralia sulcata (Ehrenberg) Kutzing

Parlibellus hagelsteinii (Hustedt) E. J. Cox

Parlibellus tubulosus (Grunow) E. J. Cox

Petrodycton gemma (Ehrenberg) D.G. Mann

Petroneis marina (Ralfs) D.G. Mann

Plagiogramma staurophorum (Gregory) Hendey

Plagiotropis $\mathrm{sp}$

Pleurosigma diversestriatum Meister

Pleurosigma formosum Wm. Smith

Pleurosigma intermedium Wm. Smith

Pleurosigma sp.

Podocystis adriatica Kutzing

Podosira stelliger (J.W. Bailey) Mann

Porosira pentaportula Syvertsen and Lange
Licmophora abreviata Agardh

Proboscia alata (Brightwell) Sündstrom

Psamodycton panduriforme (Grunow) D.G.Mann

Pseudo-nitzschia australis Frenguelli

Pseudo-nitzschia cf. delicatissima (Cleve) Heiden

Pseudo-nitzschia pungens (Grunow ex Cleve) Hasle

Pseudosolenia calcar-avis ( Schultze) Sündstrom

Rhaphoneis amphiceros (Ehrenberg) Cleve

Rhizosolenia hebetata Gran

Rhizosolenia pungens Cleve-Euler

Rhizosolenia robusta Norman

Rhizosolenia setigera Brightwell

Rhizosolenia styliformis Brightwell

Detonula pumila (Castracane) Gran

Skeletonema costatum (Greville) Cleve

Stauropsis membranacea (Cleve) Meunier

Stephanopyxis palmeriana (Grev.) Grunow

Stephanopyxis turris (Greville) Ralfs

Streptotheca tamensis Schrub

Surirella fastuosa Ehrenberg

Synedra sp.

Thalassionema nitzschioides Grunow

Thalassiosira anguste-lineata (Schmidt) Fryxell and

Hasle

Thalassiosira decipiens (Grunow) Jorgensen

Thalassiosira eccentrica (Ehrenberg) Cleve

Thalassiosira gravida Cleve

Thalassiosira leptopus Jouse

Thalassiosira nanolineata (Mann) Fryxell

Thalassiosira nodulolineata (Hasle) Hasle and Fryxell

Thalassiosira oestrupii (Ostenfeld) Hasle

Thalassiosira poroseriata (Ramsf.) Hasle

Thalassiosira punctigera (Castracane) Hasle

Thalassiosira rotula Meunier

Thalassiosira simonsenii Hasle and Fryxell

Thalassiosira subtilis (Ostenfeld) Gran

Thalassiosira tumida (Janisch) Hasle

Thalassiosira spp.

Thalassiothrix frauenfeldii Grunow

Thalassiothrix mediterranea Cupp

Thalassiosira spp.

Thalassiothrix frauenfeldii Grunow

Thalassiothrix mediterranea Cupp 